\title{
AKUNTANSI DANA DESA \\ (Studi Wacana Pada Desa Nupabomba Dan Wani II Kecamatan Tanantovea Kabupaten Donggala)
}

\author{
Mohammad Fadli' ${ }^{1}$ M. Ikbal Abdullah'2, Nina Yusnita Yamin ${ }^{2}$ \\ ${ }^{1}$ Mahasiswa Jurusan Akuntansi Fakultas Ekonomi Universitas Tadulako, Palu \\ ${ }^{2}$ Dosen Universitas Tadulako, Palu
}

\begin{abstract}
This research aimed to identify, analize, and synthesize the administration and reporting process of village funds. It used the qualitative method with discourse aprroachment. The result of this research showed that the administration process are still constrained by the limited number of human resources and lack of understanding about regulation. Reporting mechanisms undertaken by the village government seem "stiff". In addition, there is an "attachment" of village funds caused by the absence of allocation for the welfare of the village officials. which may create "space" for village officials to commit fraud. Reporting has been done vertically and horizontally.
\end{abstract}

Key words: Village Funds, Administration, Reporting

\begin{abstract}
ABSTRAK
Penelitian ini bertujuan untuk mengetahui dan menganalisis serta mensintesa wacana tentang penatausahaan dan pelaporan dana desa. Metode penelitian yang digunakan yakni metode kualitatif dengan pendekatan wacana. Hasil penelitian menunjukkan penatusahaan yang dilakukan masih terkendala keterbatasan SDM dan minimnya pemahaman tentang regulasi.Mekanisme pelaporan yang dilakukan pemerintah desa terkesan "kaku". Selain itu adanya "keterikatan" dana desa karena tidak ada alokasi untuk kesejahteraan aparat desa, sehingga hal ini dapat menimbulkan "ruang" bagi aparat desa untuk melakukan kecurangan. Pelaporan telah dilakukan secara vertikal dan horizontal.
\end{abstract}

Kata kunci: Dana Desa, Penatausahaan, Pelaporan

Jurnal Akun Nabelo: Jurnal Akuntansi Netral, Akuntabel, Objektif

Volume 1/Nomor 1/Juli 2018 Jurusan Akuntansi FE-Universitas Tadulako

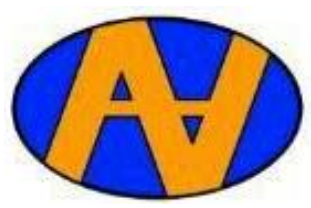




\section{A. PENDAHULUAN}

Desa merupakan bagian yang tidak bisa terpisahkan dari suatu negara berkembang. Pada negara maju, desa mulai jarang ditemukan dikarenakan rata-rata desa yang ada di negara maju telah berkembang menjadi kelurahan ataupun kota. Desa sebenarnya mempunyai peranan yang sangat penting bagi suatu negara, mulai dari potensi sumber daya alam yang melimpah dan budaya yang sangat beraneka ragam. Dalam hal perkembangannya sekarang telah banyak negara-negara yang telah memperhatikan keberadaan desa, salah satunya perhatian yang diberikan pemerintah pusat kepada desa yaitu otonomi desa, dengan adanya otonomi desa maka suatu desa berhak untuk mengelola sumber daya alam dan kebudayaannya sendiri dengan semaksimal mungkin.

Nurcholis (2011) mendefinisikan desa sebagai satuan pemerintahan yang diberi hak otonomi adat sehingga merupakan badan hukum. Desa berbeda dengan apa yang dinamakan dengan kelurahan, kelurahan bukan badan hukum melainkan hanya sebagai tempat beroperasinya pelayanan pemerintah dari pemerintah kabupaten/kota di wilayah kelurahan setempat. Sedangkan desa adalah wilayah dengan batasbatas tertentu sebagai kesatuan masyarakat hukum (adat) yang berhak mengatur dan mengurus urusan masyarakat setempat berdasarkan asal usulnya.

Anjayani (2007) mendefinisikan bahwa istilah desa yang biasa kita pakai berasal dari bahasa India "swadesi" yang artinya tempat asal, tempat tinggal, negeri asal, atau dapat diartikan sebagai tanah leluhur yang merujuk pada satu kesatuan norma hidup dan memiliki batas yang jelas. Selanjutnya, berdasarkan Undang-Undang Nomor 6 tahun 2014 tentang Desa, desa adalah kesatuan masyarakat hukum yang memiliki batas wilayah yang berwenang untuk mengatur dan mengurus urusan

pemerintahan, kepentingan masyarakat setempat berdasarkan prakarsa masyarakat, hak asal usul, dan/atau hak tradisional yang diakui dan dihormati dalam sistem pemerintahan Negara Kesatuan Republik Indonesia (NKRI).

Desa memiliki pemerintahannya sendiri. Pemerintahan Desa terdiri atas Pemerintah Desa (yang meliputi Kepala Desa dan Perangkat Desa) dan Badan Permusyawaratan Desa (BPD). Kepala Desa merupakan pimpinan penyelenggaraan pemerintahan desa berdasarkan kebijakan yang ditetapkan bersama Badan Permusyawaratan Desa (BPD). Masa jabatan Kepala Desa adalah 6 tahun, dan dapat diperpanjang untuk satu kali masa jabatan lagi. Kepala Desa juga memiliki wewenang menetapkan peraturan desa yang telah mendapat persetujuan bersama BPD. Perangkat desa bertugas membantu Kepala Desa dalam melaksanakan tugas dan wewenangnya. Perangkat Desa terdiri dari Sekretaris Desa dan perangkat desa lainnya. Salah satu perangkat desa adalah Sekretaris Desa, yang diisi dari Pegawai Negeri Sipil (PNS). Sekretaris Desa diangkat oleh Sekretaris Daerah Kabupaten/Kota atas nama Bupati/Walikota.

Kinerja suatu entitas dalam mengelola apa yang dimilikinya sebaik mungkin dapat tercermin dari laporan keuangan yang mereka buat, begitu halnya desa, dari laporan keuangan yang mereka susun dapat tercermin kinerja pemerintahan desa dalam mengelola sumber dayanya baik sumber daya alam maupun sumber daya manusia yang dimiliki dan juga dalam membangun infrastruktur yang masih dibutuhkan desa.

APBDesa terdiri dari pendapatan desa, belanja desa, dan pembiayaan desa. Pendapatan desa yang dimaksud meliputi semua penerimaan uang melalui rekening desa yang merupakan hak desa dalam 1 (satu) tahun anggaran yang tidak perlu dibayar kembali oleh 
desa. Pendapatan desa terdiri dari Pendapatan Asli Desa (PADesa), Transfer, dan Pendapatan Lain-lain. Dalam kelompok transfer itu sendiri terdiri dari Dana Desa, Bagian dari Hasil Pajak Daerah Kabupaten/Kota dan Retribusi Daerah, Alokasi Dana Desa (ADD), Bantuan Keuangan dari APBD Provinsi, dan Bantuan Keuangan APBD Kabupaten/Kota.

Dana Desa digunakan untuk membiayai penyelenggaraan pemerintahan, pembangunan, pemberdayaan masyarakat, dan kemasyarakatan. Kedua, penggunaan Dana Desa diprioritaskan untuk pembangunan dan pemberdayaan masyarakat desa sesuai dengan prioritas penggunaan Dana Desa yang ditetapkan oleh Kementerian Desa, PDT, dan Transmigrasi. Ketiga, penggunaan Dana Desa untuk kegiatan yang tidak termasuk prioritas dapat dilakukan sepanjang kebutuhan untuk pemenuhan kegiatan pembangunan dan pemberdayaan masyarakat telah terpenuhi. Keempat, penggunaan Dana Desa untuk kegiatan yang tidak diprioritaskan harus mendapatkan persetujuan Bupati/Walikota.

Agar fungsi APBDesa dapat berjalan secara optimal, maka kebijakan anggaran dan pencatatan atas penerimaan dan pengeluaran harus dilakukan dengan cermat dan sistematis pada buku administrasi keuangan desa. Di dalam setiap kehidupan organisasi, baik organisasi pemerintah, organisasi swasta, maupun organisasi masyarakat, penyelenggaraan tugas-tugas keorganisasian harus dicatat dan didokumentasikan secara baik, karena merupakan bagian dari kinerja organisasi dalam rangka mencapai tujuan organisasi tersebut.

Undang-Undang Nomor 6 tahun 2014 tentang Desa yang telah ditetapkan merupakan awal yang baru bagi desa untuk menerapkan sistem akuntansi yang lebih baik dari yang sebelumnya. Akuntansi desa sama halnya dengan akuntansi pada umumnya yang harus merujuk pada prinsip-prinsip akuntansi yang berterima umum. Akuntansi desa juga meliputi bagaimana desa melakukan manajemen keuangan dalam bentuk APBDesa dan juga laporan pertanggungjawaban yang dilakukan tiap tahunnya. Keuangan desa merupakan semua hak dan kewajiban desa yang dapat dinilai dengan uang serta segala sesuatu berupa uang dan barang yang berhubungan dengan pelaksanaan hak dan kewajiban desa. Masuknya dana yang cukup besar untuk desa mengharuskan mereka untuk melakukan pengelolaan keuangan desa yang baik, pengelolaan keuangan desa tersebut mencakup perencanaan, pelaksanaan, penatausahaan, pelaporan dan pertanggungjawaban keuangan desa.

Dalam Ketentuan Umum Permendagri Nomor 113 tahun 2014 tentang Pengelolaan Keuangan Desa disebutkan bahwa "Pengelolaan keuangan desa adalah keseluruhan kegiatan yang meliputi perencanaan, pelaksanaan, penatausahaan, pelaporan, pertanggungjawaban". Sehingga dengan hak otonom tersebut harapannya desa dapat mengelola keuangannya secara mandiri, baik mengelola pendapatan dan sumber-sumber pendapatan juga mengelola pembelanjaan anggaran.

Penatausahaan laporan keuangan desa dilakukan oleh Bendahara Desa atau KAUR (Kepala Urusan) Keuangan. Bendahara desa wajib melakukan pencatatan setiap penerimaan dan pengeluaran serta melakukan tutup buku setiap akhir bulan secara tertib. Penatausahaan penerimaan dan pengeluaran yang dicatat oleh bendahara desa menggunakan buku kas umum, buku kas pembantu pajak, dan buku bank. Bendahara desa juga wajib untuk mempertanggungjawabkan uang melalui laporan pertanggungjawaban dan laporan pertanggungjawaban disampaikan setiap bulan kepada Kepala Desa dan paling lambat tanggal 10 bulan berikutnya. Setelah melakukan penatausahaan 
selanjutnya pemerintah desa melakukan pelaporan keuangan desa.

Permendagri Nomor 113 Tahun 2014 tentang Pengelolaan Keuangan Desa pasal 35 ayat 2 mengenai penatausahaan keuangan desa termuat bahwa bendahara desa wajib melakukan pencatatan setiap penerimaan dan pengeluaran serta melakukan tutup buku setiap akhir secara tertib. Penatausahaan penerimaan dan pengeluaran yang dimaksud menggunakan buku kas umum, buku kas pembantu pajak, dan buku bank. Selanjutnya pada pasal 37 mengenai pelaporan keuangan desa termuat bahwa Kepala Desa menyampaikan laporan realisasi pelaksanaan APBDesa kepada Bupati/Walikota berupa laporan semester pertama dan laporan semester akhir tahun. Laporan semester pertama berupa laporan realisasi APBDesa yang disampaikan paling lambat pada akhir bulan Juli tahun berjalan. Sedangkan laporan semester akhir tahun disampaikan paling lambat pada akhir bulan Januari tahun berikutnya.

\section{B. METODE PENELITIAN}

Lokasi $\begin{gathered}\text { penelitian } \\ \text { pada }\end{gathered} \begin{array}{r}\text { Dni } \\ \text { Dilaksanakan }\end{array}$
Nupabomba dan Desa Wani II
Kecamatan Tanantovea Kabupaten
Donggala. Jenis penelitian ini
adalah penelitian kualitatif dengan
pendekatan wacana. Alat analisis
dan validitas data digunakan
dengan menggunakan triangulasi
sumber dan triangulasi teknik.
Teknik yang digunakan dalam
menentukan informan adalah
purposive sampling yaitu teknik
pengambilan sumber data dengan
pertimbangan tertentu (Sugiyono,
2014). Informan pada penelitian ini
adalah Kepala Seksi Administrasi,
Keuangan dan Aset Desa BPMPD
Kabupaten Donggala, kemudian
perangkat desa yang terdiri dari
sekretaris Desa Nupabomba dan
Desa Wani II serta KAUR Keuangan
Desa Nupabomba dan bendahara
Desa Wani II.

Metode analisis ini,
menganalisis data dengan cara mendeskripsikan atau menganalisis data yang telah terkumpul, yaitu mengenai wacana para informan mengenai penatausahaan dan pelaporan dana desa. Analisis data dilakukan melalui data reduction (reduksi data), data display (penyajian data) dan conclusion drawing/verification (kesimpulan/ verifikasi).

\section{HASIL DAN PEMBAHASAN}

\section{C.1 Penatausahaan: Keterbatasan SDM dan Pemahaman yang Minim \\ Penatausahaan Desa} merupakan salah satu bagian yang tidak terlepas dari proses pengelolaan keuangan desa yang harus dilakukan oleh pemerintah desa. Penatausahaan sendiri dilakukan oleh orang yang telah ditunjuk oleh Kepala Desa dalam hal ini menjabat sebagai bendahara desa maupun KAUR Keuangan desa. Penatausahaan yang dilakukan desa tentunya mengalami beberapa kendala dalam pelaksanaannya. Adapun kendala tersebut berupa Sumber Daya Manusia (SDM) dan regulasi yang ada.

Pernyataan dari Kepala Seksi Administrasi, Keuangan dan Aset Desa BPMPD Kabupaten Donggala menyebutkan bahwa untuk mengoperasikan SIMDA harus ada admin di tiap desa. Admin yang mengoperasikan SIMDA haruslah aparat desa yang betul-betul mengetahui tentang regulasi yang ada dan mengetahui penatausahaan desa. Banyak desa yang terkendala dalam penatausahaan ataupun dalam mengoperasikan SIMDA, hal itu dikarenakan SDM di desa yang kurang memadai. Hal yang sama juga dirasakan oleh desa Nupabomba dan Wani II, aparat desa yang melakukan penatausahaan jika dilihat dari latar belakang pendidikannya tidak berasal dari sarjana ekonomi, ataupun berasal dari sarjana hukum yang dapat memahami 
dengan baik regulasi yang ada. Seperti KAUR Keuangan Desa Nupabomba yang merupakan sarjana akan tetapi bukan sarjana ekonomi, begitu pula dengan Bendahara Desa Wani II yang merupakan guru olahraga, kalau melihat dari segi kualitas tentu saja orang-orang akan beranggapan bahwa kedua aparat desa tersebut kurang mampu dalam melaksanakan penatausahaan dikarenakan hal tersebut bukan bidang mereka.

Selain aparat desa yang melakukan penatausahaan, keterbatasan SDM juga terjadi pada aparat desa yang memangku jabatan untuk melakukan pelaporan desa, dalam hal ini sekretaris desa. Sekretaris Desa Wani II merupakan tamatan Sekolah Menengah Atas (SMA), sedangkan Sekretaris Desa Nupabomba yang merupakan tamatan SMA akan tetapi sempat menempuh kuliah di jurusan Matematika dan Ilmu Pengetahuan Alam (MIPA) dan tidak menyelesaikan kuliahnya. Keterbatasan SDM yang ada di desa dapat dilihat dari data desa yang ada, data Desa Wani II menunjukkan sebanyak 101 jiwa merupakan sarjana. Angka tersebut terbilang cukup sedikit apabila dilihat dari jumlah penduduk Desa Wani II yang berjumlah 3.976 jiwa. Desa Nupabomba juga mempunyai masalah keterbatasan SDM, data di desa tersebut menunjukkan sebanyak 49 jiwa merupakan tamatan S1, sedangkan 20 jiwa merupakan tamatan D3, hal itu terbilang sedikit apabila melihat jumlah penduduk Desa Nupabomba yang mencapai 3.011 jiwa.

Selain dari keterbatasan SDM, desa masih belum memahami dengan baik regulasi yang ada, terutama format tentang penatausahaan yang telah ditetapkan. Format baku dalam melakukan penatausahaan tentunya telah ditentukan di dalam peraturan yang ada dan telah dilaksanakan oleh setiap desa diseluruh Indonesia, tidak terkecuali Desa Nupabomba dan Wani II.

Kepala Seksi BPMPD sendiri menyesalkan berita acara penutupan kas yang sebelumnya ada dalam BKU dihilangkan dalam Permendagri Nomor 113 Tahun 2014 tentang Pengelolaan Keuangan Desa, berita acara penutupan kas sendiri sebenarnya membantu kepala desa dalam mengawasi kinerja dari bendahara maupun KAUR keuangan. Dikarenakan dalam berita acara penutupan kas kepala desa berhak bertanda tangan dalam berita acara tersebut sehingga kepala desa mengetahui dengan jelas saldo keuangan yang dimiliki desa tersebut.

BPMPD Kabupaten Donggala mengambil langkah untuk memodifikasi BKU dengan menambahkan berita acara penutupan kas. BPMPD Kabupaten Donggala sendiri yang membuat format penutupan kas. Dalam format tersebut tercantum nominal saldo kas dan harus ditandatangani oleh Bendahara dan Kepala Desa.

Melihat lampiran Permendagri Nomor 113 tahun 2014 tentang Pengelolaan Keuangan Desa (lihat lampiran III), memang benar bahwa berita acara penutupan kas tidak ada dalam regulasi yang baru. Akan tetapi, dilihat dari segi substansinya, apa yang telah ada dalam regulasi sebenarnya sama dengan apa yang diinginkan oleh BPMPD Kabupaten Donggala. Hanya saja dalam regulasi sebelumnya terdapat berita acara penutupan kas dimana pada regulasi baru telah dihilangkan. Sebenarnya berita acara penutupan kas yang ingin melihat saldo akhir keuangan desa, juga bisa dilihat pada kolom saldo yang ada dalam regulasi baru. Hal ini mengindikasikan minimnya pemahaman tentang regulasi. BPMPD kabupaten Donggala hanya terpaku dengan format yang ada, sehingga apabila terdapat 
perubahan, BPMPD langsung memerintahkan desa untuk mengikuti perubahan tersebut. Padahal dalam perubahan tersebut secara substansi menunjukkan tujuan yang sama. Hal ini berakibat penatausahaan yang dilakukan terlihat kaku.

\section{C.2 Pelaksanaan Pelaporan yang "Kaku"}

Pelaporan yang merupakan salah satu bagian dari pengelolaan keuangan desa juga tidak lepas dari format yang ada. Format yang ditetapkan mengenai proses pelaporan yang nantinya akan dilaporkan ke pemerintah daerah. Kepala Seksi BPMPD menjelaskan bagaimana mekanisme yang dilakukan oleh PTPKD dalam membuat laporan. Dalam penjelasannya setiap anggaran yang ingin digunakan terlebih dahulu harus melewati verifikasi Sekretaris Desa selaku koordinator PTPKD. Baru kemudian disetujui oleh Kepala Desa. Verifikasi dari Sekretaris Desa dimaksudkan agar penggunaan anggaran sesuai dengan apa yang telah ditetapkan maupun aturan yang berlaku. Hal yang dilakukan desa dalam membuat laporan memang sesuai mekanisme penandatanganan yang berlaku. Akan tetapi hal tersebut terkesan kaku dikarenakan belum ada paraf dari Sekretaris maka Kepala Desa tidak ingin bertanda tangan, jika terjadi kejadian di mana Sekretaris sedang berada di luar kota karena suatu kepentingan, maka pelaporan belum bisa dilaksanakan karena terkendala tidak adanya Sekretaris. Seharusnya pemerintah desa sudah menunjuk selain Sekretaris untuk melakukan hal tersebut, sehingga pelaporan nantinya tidak terlambat dikarenakan Sekretaris tidak ada.

Pelaporan terlambat masuk juga bisa dikarenakan pergantian kepemimpinan ataupun ada aparat desa yang mengundurkan diri. Sebenarnya hal tersebut tidak bisa dijadikan alasan kenapa pelaporan terlambat masuk, seharusnya apabila ada yang mengundurkan diri pemerintah desa cepat tanggap dalam mengambil alih tugas dari aparat yang telah mengundurkan diri. Seperti ada Kepala Desa yang mengundurkan diri, seharusnya secara struktural Sekretaris Desa langsung mengambil alih jabatan sementara agar pelaporan tidak terlambat dilaksanakan. Hal-hal seperti inilah yang sebanarnya membuat pelaporan di desa bersifat kaku, sehingga pelaporan yang sebenarnya sudah masuk masa tenggang akan tetapi belum dilaporkan sama sekali.

Proses penyusunan anggaran membantu pemerintah mencapai tujuan fiskal dan meningkatkan koordinasi antar bagian dalam lingkungan pemerintah, penyusunan anggaran sektor publik pada dasarnya memberi informasi rinci kepada DPR/DPRD dan masyarakat tentang program yang meningkatkan kualitas kehidupan rakyat, dan bagaimana programprogram tersebut dibiayai. Proses penyusunan anggaran sangat penting bagi setiap organisasi untuk memenuhi kebutuhan setiap program di mana dalam proses penyusunan anggaran hal yang perlu diperhatikan yaitu kebutuhan berapa banyak atau seberapa besar anggaran yang dibutuhkan guna membiayai program-program yang telah direncanakan.

\section{C.3 "Keterikatan" Dana Desa \\ Penggunaan}

Dana desa pada tahun 2015 digunakan hanya dalam empat bidang saja yaitu bidang penyelenggaraan pemerintahan, bidang pembangunan, bidang pemberdayaan dan bidang pembinaan. Hal tersebut membuat dana desa yang akan digunakan sangatlah bersifat terikat karena dana desa yang digunakan untuk empat bidang saja. Apabila ada hal yang ingin dilakukan desa diluar dari empat bidang tersebut maka desa harus menggunakan Alokasi Dana Desa (ADD) yang berasal dari Kabupaten.

Dana desa pada tahun 2016 mengalami perubahan regulasi, 
yang sebelumnya diterbitkan Permendes Nomor 5 kemudian digantikan oleh Permendes Nomor 21 tentang Penggunaan Dana Desa. Penggunaan dana desa diperbolehkan digunakan untuk dua bidang saja, yaitu bidang pembangunan dan bidang pemberdayaan masyarakat. Adanya peraturan yang baru membuat dana desa ini menjadi lebih terikat dengan hanya boleh digunakan pada dua bidang saja, sehingga ini lagi-lagi menjadi keluhan bagi aparat desa.

Sekretaris Desa Nupabomba mengatakan bahwa dengan adanya perubahan penggunaan dana desa dari Permendes Nomor 5 ke Permendes Nomor 21 membuat dana desa ini menjadi betul-betul terikat. Dalam regulasi tersebut penggunaan dana desa digunakan untuk dua bidang saja, dan tidak boleh untuk digunakan untuk kesejahteraan aparat walaupun hanya sedikit. Dana desa yang bersifat terikat ini dapat menimbulkan sebuah kecurangan atau disebut dengan fraud yang akan dilakukan oleh aparat dikarenakan tidak adanya alokasi dana untuk kesejahteraan aparat.

Fraud bisa saja terjadi di kalangan aparat desa dikarenakan dana desa tidak ada digunakan untuk kesejahteraan aparat sehingga mereka dapat melakukan rasionalisasi yang merupakan salah satu dimensi fraud triangle. Aparat desa mungkin akan berpikir mereka yang melakukan pengelolaan keuangan desa akan tetapi dana tersebut sedikitpun tidak ada untuk kesejahteraan mereka. Mereka yang telah melakukan pengelolaan keuangan dengan baik bahkan melaporkan dana tersebut tepat pada waktunya akan tetapi tidak ada reward untuk mereka, yang minimal reward tersebut berupa alokasi dari dana desa untuk kesejahteraan aparat.

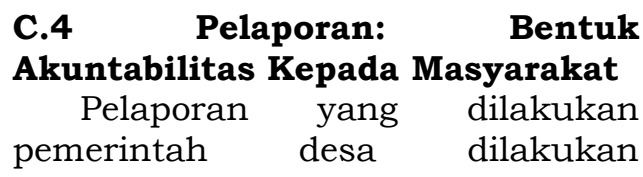

sebanyak dua kali, bentuk dari pelaporan sendiri berisi tentang penggunaan anggaran ang telah dilakukan oleh desa dalam semester pertama dan penggunaan anggaran keseluruhan yang dilaporkan pada semester terakhir.

Pemerintah Desa telah melakukan pelaporan, pelaporan yang dimaksudkan hampir sama dengan makna pertanggungjawaban atau yang biasa disebut dengan akuntabilitas. Akuntabilitas sendiri menurut Mardiasmo (2009) terbagi atas dua macam, yaitu akuntabilitas vertikal dan akuntabilitas horizontal. Pelaporan diberikan ke BPD, kabupaten, dan kecamatan dalam hal ini pelaporan yang dilakukan secara vertikal. Pelaporan secara vertikal yaitu memberikan pelaporan kepada otoritas yang lebih tinggi. Selain itu pemerintah desa juga melakukan pelaporan kepada masyarakat, pelaporan ini dapat dinamakan pelaporan secara horizontal di mana pelaporan ini diperuntukkan untuk masyarakat luas. Pemerintah Desa memberikan pelaporan kepada masyarakat berupa informasi setiap pelaksanaan Dana Desa agar tercipta transparansi dan juga akuntabilitas

\section{PENUTUP}

\section{D.1 Kesimpulan}

Hasil penelitian ini menemukan bahwa penatausahaan yang dilakukan desa masih terkendala keterbatasan SDM baik secara kualitas maupun kuantitas. Pelaporan yang dilakukan oleh pemerintah desa terkesan kaku dikarenakan mekanisme pelaporan yang dilakukan harus melalui persetujuan Kepala Desa dan Sekretaris Desa. Alokasi penggunaan dana desa tidak sepeser pun untuk kesejahteraan aparat, dengan dana desa yang begitu terikat dapat menimbulkan ruang bagi aparat untuk melakukan fraud. Pelaporan yang dilakukan desa merupakan pelaporan yang bersifat horizontal dan vertikal. . 


\section{D.2 Saran}

1. Sosialisasi yang lebih ditingkatkan mengenai sistem keuangan desa, dan disarankan untuk menggunakan sistem yang lebih mudah dipahami masyarakat desa.

2. Sebagai pijakan bagi peneliti selanjutnya untuk melakukan penelitian yang sama dengan alat atau pendekatan yang berbeda, sehingga hasil pengamatan mengenai pelaporan dan penatausahaan desa dapat berbeda, peneliti selanjutnya disarankan menggunakan analisis kritis, sehingga bila terdapat wacana permasalahan di desa maka peneliti selanjutnya bisa mengkritisi sekaligus memberikan solusi dari permasalahan yang ada.

\section{D.3 Keterbatasan Penelitian}

Keterbatasan utama yang dihadapi dalam proses penelitian ini berkaitan dengan minimnya dokumen-dokumen pendukung yang ada di Desa Wani II, sehingga membuat peneliti tidak dapat menyajikan hasil pengamatan secara menyeluruh mengenai penatausahaan dan pelaporan di Desa Wani II.

\section{DAFTAR PUSTAKA}

Anjayani, Eni. 2007. Desaku Masa Depanku. Penerbit Cempaka Putih. Klaten.

Bungin, Burhan. 2010. Penelitian Kualitatif. Kencana Prenada Media Group. Jakarta.

Creswell, John W. 2014. Research Design: Pendekatan Kualitatif, Kuantitatif, dan Mixed. Edisi Ketiga. Pustaka Pelajar. Yogyakarta.

Harahap, Sofyan Syafri. 2015. Teori Akuntansi. Edisi revisi. PT.Rajagrafindo Persada. Jakarta.

Kadek, Darmiasih dkk. 2012. Analisis Mekanisme Penyaluran Alokasi Dana Desa (ADD) Pada Pemerintah Desa (Studi Kasus Desa Tri Buana, Kec. Sidemen, Kab.
Karangasem). akuntansi.

Pendidikan

Singaraja.

Karyono. 2008. Forensic Fraud. Edisi 1. Penerbit ANDI. Yogyakarta.

Mardiasmo. 2009. Akuntansi Sektor Publik. Penerbit ANDI. Yogyakarta.

Moleong, Lexy J. 2013. Metode Penelitian Kualitatif. Penerbit Remaja Rosdakarya. Bandung.

Nurcholis, Hanif. 2011. Pertumbuhan dan

Penyelenggaraan

Pemerintahan Desa. Penerbit Erlangga. Jakarta.

Peraturan Menteri Dalam Negeri Nomor 35 Tahun 2007 Tentang Pedoman Umum Tata Cara Pelaporan dan Pertanggungjawaban

Penyelenggaraan Pemerintah Desa.

Peraturan Menteri Dalam Negeri Nomor 113 Tahun 2014 Tentang Pengelolaan Keuangan Desa.

Peraturan Pemerintah Nomor 22 Tahun $2015 \quad$ Tentang Perubahan Atas Peraturan Pemerintah Nomor 60 Tahun 2014 Tentang Dana Desa Yang Bersumber Dari Anggaran Pendapatan Dan Belanja Negara.

Peraturan Pemerintah Nomor 47 Tahun 2015 Tentang Perubahan Atas Peraturan Pemerintah Nomor 43 Tahun 2014 Tentang Pelaksanaan Undang-undang Nomor 6 Tahun 2014 Tentang Desa.

Sugiyono. 2014. Memahami Penelitian Kualitatif. Penerbit CV Alfabeta. Bandung.

Undang-undang Nomor 6 Tahun 2014 Tentang Pemerintah Desa. 